\title{
Exploring employee retention and intention to leave within a call centre
}

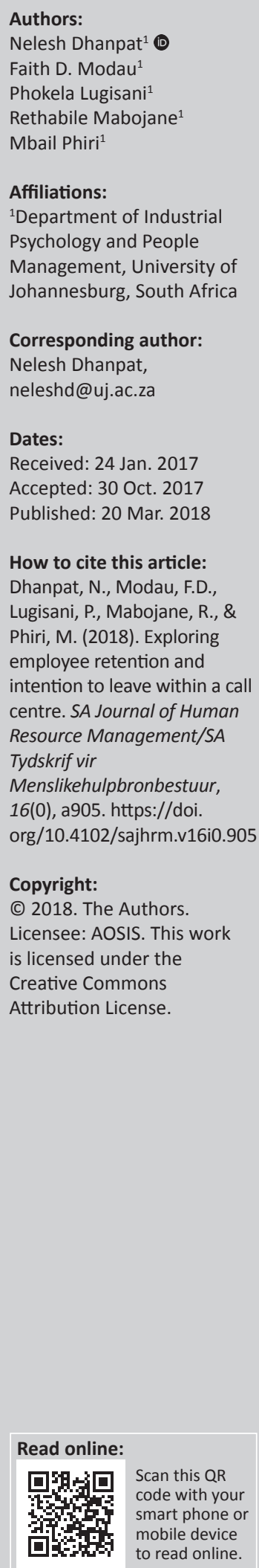

Orientation: Call centre organisations are plagued with high levels of employee turnover and are challenged by effectively retaining their staff.

Research purpose: The study sets out to establish factors that affect the retention of call centre agents and to determine call centre agents' intention to leave.

Research design, approach and method: The study is quantitative in nature, which follows a cross-sectional approach. Data were collected using an established questionnaire, the retention factor management scale. Psychometric properties of the questionnaire for validity and reliability were assessed using factor analysis and Cronbach's alpha coefficient, respectively, to ensure internal consistency. Data were collected using a convenience sample, and the participants of the study are call centre agents. The sample yielded a response rate of 282 respondents. Subsequently, data were analysed using descriptive and inferential statistics.

Main findings: The findings reflect that a relationship between the retention factors and intention to leave exists, whereby compensation contributes the most towards intention to leave.

Practical and managerial implications: Recommendations are made for the retention factors of call centre agents, which when implemented have the potential to enhance employee retention.

Contribution: The study provided valuable insights to management within call centre organisation towards employee retention and provided recommendations and strategies aligned to factors that will enhance retention, which human resource practitioners need to be cognisant of.

\section{Introduction}

The investment in human capital has profound implications for organisations. It is with this in mind that employees are viewed as an asset in any organisation. It can be said that 'no technology can replace skilled communication, problem solving, and customer focus' (Jacobs \& Roodt, 2011, p. 1). Organisations may find it easier to attract people; however, retaining them may be a great challenge as people are motivated by various factors (Grobler, Wärnich, Carrell, Elbert \& Hatfield, 2011). Employee retention is considered to be one of the biggest challenges affecting organisations (Das, Nandialath \& Mohan, 2013). Turnover is a concern in organisations worldwide (Amah 2009) which reduces the operating costs of organisations, leaving significant implications with regard to the loss of human capital and interruptions in organisational activities (Takawiara, Coetzee \& Schreuder, 2014).

Issues affecting employee retention include job satisfaction, organisational commitment, emotional labour, person-organisation fit, sense of coherence, perceived organisational support and leadermember relationship (Das et al., 2013; Goodwin, Groth \& Frenkel, 2011; Harry \& Coetzee, 2013; Joāo \& Coetzee, 2012; Mcculloch \& Turban, 2007; Wang, Wang, Xu \& Ji, 2014). There are several factors that affect employee retention, which include compensation, career opportunities, material working conditions and training and development (Pierre \& Tremblay, 2011). It is essential that organisations retain talent in order to gain a competitive advantage. Essentially, organisations need to focus on retaining skilled employees and keeping them engaged in their jobs.

\section{Background to study}

The call centre industry is the world's fastest growing industry from the beginning of the 21st century (Pillay, Buitendach \& Kanengoni, 2014). According to Simons and Buitendach (2013), the 
number of employees within the South African call centre sector increased from 50000 in 2005 to 180000 in 2010. Furthermore, it was predicted that by 2015 approximately 100000 new jobs would be created in South Africa. A call centre is defined as an interactive work environment, whereby call centre agents are the main mediators of business by means of computer-based and telephone-based technologies (Pierre \& Tremblay, 2011). The computer-based and telephone-based technologies enable the fast and efficient distribution of incoming calls and/or allocation of outgoing calls to available staff, and allow for interaction between customer and call centre agent to occur simultaneously with the use of display screen equipment and the instant access to, and inputting of information.

The levels of complexity in call centre jobs vary and they comprise unskilled call centre agents and/or highly skilled agents (Jacobs \& Roodt, 2011; Pierre \& Tremblay, 2011). Call centre organisations are characterised by high technologybased work, high work pressure and work overload, which lead to stress and burnout, absenteeism and performance problems (Simons \& Buitendach, 2013). This results in employees seeking alternative employment. Therefore, call centres need to find ways of retaining their staff.

Management within the call centres is seen to have power, which is closely linked with that of Taylorism (Taylor \& Bain, 1999). With an increase in managerial power, their work is often fragmented by extensive monitoring and controlling of agents through the use of technology, whilst defining practices that may enhance employee well-being and customer satisfaction (Neely, Bourne \& Kennerly, 2003). Effective managerial skills assist in reducing employee turnover (Gayathri, Sivaraman \& Kamalambal, 2012). Consequently, ineffective management skills will result in agents becoming frustrated and hence leaving their organisation (Tse, Huang \& Lam, 2013).

\section{Focus of the study}

The call centre industry is growing enormously. A challenge that exists in most call centre organisations is the extreme employee turnover rates (Van Rensburg, Boonzaier \& Boonzaier, 2013). According to Pierre and Tremblay (2011), turnover rates of call centres were $70 \%$ and increased by $30 \%$ from 2008 to 2011. The work environment is associated with impaired employee well-being, namely, shift work resulting into absenteeism and increased turnover rates. Likewise, Van Rensburg et al. (2013) indicated high stress levels, high employee turnover and emotional burnout as factors associated with call centres. Call centre work places a high burden on employees (Pillay et al., 2014). Previous research identified different factors that contribute to the retention of call centre agents (Das et al., 2013; Goodwin, Groth \& Frenkel, 2011; Harry \& Coetzee, 2013; Joāo \& Coetzee, 2012, p. 69; Mcculloch \& Turban, 2007; Wang et al., 2014). The call centre industry is in a poor state regarding people management practices. Managers' unwillingness to compromise efficiency for quality customer service on the expense of call centre representatives affects the well-being of those representatives (Van Rensburg et al., 2013). However, it was not indicated which of those factors contributes to the retention of call centre agents within the South African context. Therefore, this study aims to identify factors that affect the retention of call centre agents, determine their intention to leave and explore the differences among biographical groups.

\section{Literature review}

\section{Employee retention}

Fluctuations in the economy, changes in demographics and in businesses locally and abroad, have caused organisations to shift their attention towards the retention of staff. The underlying reason for this is that employees carry the skill sets and knowledge required for optimal organisational functioning (Kyndt, Dochy, Michielsen \& Moeyaert, 2009). According to Kyndt et al. (2009), employees' knowledge and skills are central to an organisation's ability to remain economically competitive. Jacobs and Roodt (2011) stated that the retention of employees has become a challenge. There is a need for retention strategies to keep employees in the organisation by reducing their intention to leave. Notably, such strategies are used for managing employees who are talented by trying to keep them in the organisation for a longer period compared to competitors by using strategic retention management initiatives (Dhanpat \& Parumasur, 2014). For an organisation to thrive in the changing world of work, there is a need to attract, develop and retain talent with the right skills and knowledge that will enhance organisational effectiveness and efficiency. Pierre and Tremblay (2011) argued that call centre managers face the difficulty of retaining their employees, resulting in high turnover rates. In the call centre industry, employee retention still lacks management support and fair labour practices. Hence, turnover rates are increasing because of unsatisfactory psychosocial states of call centre agents and work-related stressors. Notably, in understanding the challenges faced by organisations to retain employees, it is essential to understand turnover.

\section{Turnover}

Employee turnover refers to an organisation's inability to retain their employees. A challenge that exists is the high rate of employee turnover (Van Rensburg et al., 2013). Employee turnover is defined as:

the rate at which employees leave the organisation on an annual basis, and this can be expressed as a percentage, by dividing the number of employees who have left over the year by the total number of employees who were with the organisation at the beginning of the year. (Altarawmneh \& Al-Kilani, 2010, p. 47)

Notably, employee turnover stems from employees' intentions to leave the organisation. Intention to leave is defined as 'an employee's decision to leave the current job and look onwards to find another job in the near future' (Rizwan, Arshad, Munir, Iqbal \& Hussain, 2014, p. 4). This decision may be initiated by job dissatisfaction that is caused 
by work conditions such as lack of work-life balance, less money, boring work, poor supervision and lack of advancement opportunities (Smit, Stanz \& Bussin, 2015). Call centre work is commonly characterised by such work conditions.

The way employees view work has changed in such a way that it is no longer about working just to get paid. Rather, employees prefer work that is challenging, offers growth opportunities, compensates fairly and enables them to achieve work-life balance (Meier, Austin \& Crocker, 2010). Failure for an organisation to meet these needs may lead to an employee's intention to leave. However, call centre organisations may not be able to meet such needs (Simons \& Buitendach, 2013). Hence, managers need to understand why employees want to leave the organisation in order to develop programmes to mitigate their intentions (Khan \& Du, 2014). By doing so, organisations will avoid potential costs associated with replacing employees (Van Rooyen, Du Toit, Botha \& Rothmann, 2010).

For the purpose of this study, the definition is simplified as the process by which employees move out of the organisation. Turnover can be differentiated into voluntary and involuntary, functional and dysfunctional, and avoidable and unavoidable (Fleisher, 2011).

\section{Types of turnover}

Voluntary turnover and involuntary turnover refer to whether or not the termination of contract was initiated by the individual or the organisation (Fleisher, 2011; Nagadevara, Srinivasan \& Valk, 2008; Takawira, Coetzee \& Schreuder, 2014). The process of voluntary turnover begins with the employee, whilst involuntary turnover is initiated by the organisation (Allen, Bryant \& Vardaman, 2010).

Functional turnover and dysfunctional turnover refer to turnover that is desirable in contrast to turnover that is not desirable. Functional turnover results when poor performers or employees who do not fit into the culture of the organisation leave the organisation. Functional turnover involves employees who can be easily replaced (Allen et al., 2010).

Avoidable turnover and unavoidable turnover involve the viability of an organisation to avoid or prevent turnover (Fleisher, 2011). Avoidable turnover takes place because of factors that are within the organisation's capability to change, for example, higher rewards. In contrast, unavoidable turnover takes place because of factors the organisation has no control over such as death of an employee (Allen et al. 2010). High turnover rates are a gateway to understaffing resulting in increased workloads to the remaining employees and continuous drain in programme funds, as new employees will need to be recruited, and the entire process of interviews, hiring, placement and induction further strains organisational finances (Marinucci et al., 2013). An investigation into retention factors and intention to leave begins to unpack the causes of voluntary, avoidable and dysfunctional turnover.

\section{Turnover intention}

Turnover intention is defined as 'the subjective estimation of an individual regarding the probability of leaving the organisation in the near future' (Kashyap \& Rangnekar, 2014 , p. 224), and it focuses on an employee's decision to quit their job. The decision may be initiated by job dissatisfaction because of lack of appreciation, less money, boring work, poor supervision or inability to take time off (leave) (Smit et al., 2015). Turnover intention results from a mismatch between the organisation and the individual employee from the concept of person-organisation fit that leads to job dissatisfaction. When an organisation cannot supply what the employee needs, or when the employee cannot supply what the organisation needs, then there is imbalance in the person-organisation relationship (Jacobs \& Roodt, 2011).

Turnover intentions are likely to lead to voluntary turnover because the decision is initiated by the employee, as compared to the decision being initiated by the organisation, whereby the employer terminates the contract of the employee (Allen et al., 2010). The root cause of voluntary turnover may be because of organisational practices such as unfair treatment of employees, and involuntary turnover may be because of the employee's own doing such as theft or damage of the employer's property leading the employer to terminate the employment relationship. Employees' general decision to leave the organisation results in them seeking alternative employment or accepting a job offer from another organisation (Kashyap \& Rangnekar, 2014). Thus, the retention of employees is necessary as the decision of an employee to stay or leave is potentially costly to the organisation (Van Rooyen et al., 2010).

\section{Retention and turnover in the South African call centre industry}

The growth of the South African call centre industry has been exponential and had an estimated growth of 50 000-180 000 from 2005 to 2010. It was estimated that approximately 100000 new jobs were created in 2015. In other countries, call centre work is characterised by work overload, fast changing technology, change in product and services, and employees working under pressure. Such a working environment is likely to lead to stress, burnout and performance problems (Simons \& Buitendach, 2013). Barnes (2013) noted that retaining call centre agents in the industry is challenging because turnover is much higher than in other fields of employment. According to Van Rensburg et al. (2013), negative issues related to call centre work environments impact the well-being of employees in terms of long hours of work. This results in absenteeism, increased turnover and negative health-related issues leading to high stress levels and hence results in burnout. Notably, favourable working conditions create higher job satisfaction and a lower intention to leave. However, the call centre environment is characterised by repetitive and monotonous work, unchallenging work, rigid procedures, use of surveillance, lack of resources, restricted work procedures, unfair labour practices and uninteresting organisation culture. All these correlate with 
the intention to leave the organisation (Barnes, 2013). This background highlights the necessity to identify the factors that influence the retention of call centre agents so that the costs associated with the exiting of employees in the organisation can be reduced (Barnes, 2013). There is a need to identify factors affecting the retention of employees, and hence it may enhance retention strategies such as compensation, job content, training and development, supervisory support, career advancement and work-life balance.

Compensation is critical in contractual and implied agreements between the employer and the employee (Chew \& Chan, 2005). It is largely known to play a vital role in attracting employees; it enhances employee's organisational commitment and ensures employee retention. Armache (2014) stated that compensation includes wages and other forms of payments such as bonuses, profit sharing, overtime pay and sales commission. It may also include non-cash assets such as a car, housing paid by the company, company benefits and stock options. A call centre environment comprises of younger individuals who are at an early stage of their careers. Furthermore, it is characterised by low pay (Harry \& Coetzee, 2013). Therefore, salary matters are a primary precursor of employee turnover in most call centres. Research by Pierre and Tremblay (2011) indicated an external and internal salary comparison done by agents in their work environments as a confirmation of their low cash pay levels, results to dissatisfaction, absenteeism and increased turnover.

Job content refers to the nature of the job, and this may have an influence on employee's decision to leave or stay within the organisation. A mismatch between the employee's knowledge and skills and the job demands leads to stress (Jacobs \& Roodt, 2011). If an employee does not have the necessary skills, knowledge and attitude to perform his or her job, it may lead to frustration and job dissatisfaction. Call centre jobs are characterised as repetitive in nature, lacking creativity and flexibility which leads to an increase in stress levels and boredom (Harry \& Coetzee, 2013). Call centre work is also stressful in nature because it is driven by targets. Notably, call centre agents' work is constantly monitored electronically and agents are often exposed to abusive callers (Filwood, 2014). Such negative characteristics of a call centre work may lead to employees leaving the organisation.

Training and development provide opportunities for employees to develop in their career (Van Dyk \& Coetzee, 2012). It has a positive psychological effect to employees because they might perceive that the organisation value them and in turn they will remain committed to the organisation. Döckel, Basson and Coetzee (2006) stated that employees will stay in the organisation that provides an opportunity to grow by training and developing them and thus applying their acquired skills and knowledge. Furthermore, companies that provide training and development opportunities to their employees may have a psychological influence on them.
Training equips employees with the skills and knowledge that are required to perform their work effectively, and hence, employees become satisfied with their work because they know what they are doing (Armache, 2014). Call centre work is associated with minor room for progression and individual growth as vocational development is infrequent in such institutions (Coetzee \& Harry, 2015). It is likely that a lack of growth and continuous development may result in boredom and in employee intentions to seek alternative employment elsewhere.

Supervisory support refers to behaviour of the supervisor that upholds the continuous high performance of employees, such as reward, recognition and feedback (Döckel et al., 2006). Proper and frequent feedback is important to retain employees because perceived organisational support increases the affective commitment of employees in the long term. Van Dyk and Coetzee (2012) emphasise that supervisory support can be viewed as a source of trust in an employee's willingness or drive to be the best in whatever they do. Support from their supervisors reduces work-related stress levels and may create a sense of belonging which provides employees with enough reasons to stay in the organisation.

Personal outreach of supervisors to employees plays a vital role in employee retention, as focus has shifted from monetary factors (i.e. compensation) to more intrinsic factors (i.e. organisational support) (Cianni \& Guddy, 2012). Pierre and Tremblay (2011) also elaborated that extensive authoritative measures used by managers to monitor employees in their organisation, managers of most call centres listen during calls, which generally are recorded. The record keeping of agents' calls results in high levels of uncertainty and discomfort as agents experience feelings of being watched which decreases their levels of job satisfaction. This is indicative of uncomfortable emotional work which is embedded in most call centres.

Career advancement refers to an organisation's adherence to career-oriented practices and job security which leads to employee commitment (Döckel et al., 2006). Shoaib, Noor, Tirmizi and Bashi (2009) described career advancement as an organised and formalised system with planned efforts to the success of both individual career needs and organisational objectives in order for the organisation to gain and maintain a competitive advantage. Van Dyk and Coetzee (2012) emphasised that career advancement may be internal or external career opportunities. Internal career advancement improves the employees affective commitment to the organisation and hence less intention for employees to leave the organisation.

The outcomes of career development are beneficial to both individual employees and the organisation. Employees need new challenges to gain new competencies, and at the same time, promotion comes with extra income; on the contrary, the organisation will have talented and motivated employees 
who will contribute to organisational sustainability and competitive advantage. If employees perceive that they have a better chance to grow or get promoted within the organisation, then they could perform better and reduce their intention to leave. Not all employees may enjoy performing the same job forever, some employees may want to grow and get promoted to more challenging work with more money.

Lack of opportunities to grow may result in job dissatisfaction and lead to employees seeking for better and more challenging to stimulate their growth. In call centre work, not many skills acquired are relevant for progression into other fields as their type of work is governed by routinised activities (Harry \& Coetzee, 2013). With the objective to influence agents to stay longer, some call centres guarantee security at least for a medium term whilst agents with least extensive experience and lack of efficiency are not retained (Pierre \& Tremblay, 2011).

Work-life balance refers to a synchronised balance between work life and family life, and hence, there is no conflict between these two dimensions of an employee's life (Mafini \& Dlodlo, 2014). Work-life balance is described as the ability of employees to integrate their work and family commitments as well as other non-work responsibilities and activities (Van Dyk \& Coetzee, 2012). It has been noted that organisational work-life balance policies positively influence employees' psychological attachment to their organisations as they perceive that the organisation cares for them. Döckel et al. (2006) emphasised the importance of work-life balance policy by indicating that a flexible work scheduling is necessary, with policies allowing periods away from work for employees to take care of their family matters. Coetzee and Harry (2015) noted that high levels of hardiness and career adaptability are significant aspects that call centre agents can use to balance their lives and their demanding work life. Hardiness is regarded as a set of stress-resilient personality characteristics, whilst career adaptability is the ability to adjust to the working prescriptions and demands of call centre environment (Coetzee \& Harry, 2015). The call centre environment is characterised by work pressure and high workloads, causing an employee to work longer hours to meet deadlines (Simons \& Buitendach, 2013). This may cause conflict in work-life balance, leading to exhaustion and employees exiting the organisation.

\section{Gender differences in call centres and links to retention and turnover intention}

Call centre work can be characterised as female dominated. According to Bonds (2006), approximately $70 \%$ of the call centre agents are made up of a female staff complement. Notably, female call centre agents display effective interpersonal and communication skills. Although male and female call centre agents perceive the work environments differently, it can be noted that male call centre agents are better at call centre work (Korvajärvi, 2009). Hence, there may be a need that call centre organisations equally retain both male and female call centre agents. There are limited studies on gender and employee retention. For example,
Du Plooy and Roodt (2013) indicated that genders differ in how they respond to stimuli which are likely to lead to different withdrawal behaviours. In terms of turnover intentions, gender moderates this relationship intentions (Burke, Koyuncu \& Fiksenbaum, 2008; Karatepe \& Aleshinloye, 2009). With regard to career advancement, female employees differ from male employees, as their counterparts advance faster in organisations with higher levels of pay (Phillips \& Irmhoff, 1997).

\section{Strategies to enhance employee retention}

It is important to note that when organisations recruit people with the appropriate skills, they develop and implement retention strategies to prevent them from leaving (Smit et al., 2015). Retention strategies include measures taken by the organisation to keep employees. Organisations can gain a competitive advantage by being proactive in terms of introducing innovative human resource practices that can be used as strategies to retain employees, namely, offering a great work environment that is safe and healthy, competitive compensation and benefit packages, allowing employees freedom to make choices on how they will perform their duties. Furthermore, training opportunities, career development, trust and fairness between employees and the employer, regular and fair performance appraisals, potential development and succession planning (Kashyap \& Rangnekar, 2014) assist with better retention. Filwood (2014) emphasised on job security as a strategy to retain employees. Call centre jobs are characterised by short-term contracts, and contracts that are on a permanent basis motivate employees to stay in the organisation (Harry \& Coetzee, 2013). Armache (2014) also emphasised that by using retention strategies, employees will be highly satisfied and motivated, leading to higher productivity and decreased employee turnover. Although organisations may try to implement those retention strategies, it does not guarantee that all employees will stay with the organisation because an employee can still choose to leave (Kyndt et al., 2009). The reason behind this may be because the employee dislikes the manager or encounters conflict with other colleagues.

\section{Research objectives}

The objective of the study was to look at the relationship between retention factors and intention to leave which were tested empirically.

The following are sub-objectives of the study:

- to determine whether male or female call centre agents experience higher or lower intention to leave

- to explore the link between retention factors and intention to leave

- to understand which factors male and female employees perceive as an important factor of retention.

\section{Value-add of the study}

This study contributes to the existing body of knowledge regarding employee retention and human resource practices surrounding this phenomenon. Insights are provided within 
a South African context of a call centre. The study contributes theoretically and empirically towards research on employee retention and intention to leave, whilst noting relationship between the retention factors and intention to leave. The study further determines the best predictor for the retention of call centre agents.

\section{Research method \\ Research approach}

This study used a quantitative research approach and is cross-sectional in nature which is characterised by studying a particular phenomenon at a particular time. The research investigated the relationship between retention factors and intention to leave.

\section{Participants}

The target population of the study were call centre agents. Participants of the study were from a large insurance call centre situated in Johannesburg. The company had approximately 500 call centre agents as employees. A nonprobability sampling design was selected and a convenience sample was utilised. Questionnaires were handed out to agents on two consecutive days. Out of 347 questionnaires handed out, $282(81.27 \%)$ completed questionnaires were received. According to Sekaran and Bougie (2013), the acceptable sample size for a population of 500 is 260 . The sample of the population was made up of $66 \%$ female employees and $34 \%$ male employees. In terms of age, $49 \%$ were 18-24 years old, $46 \%$ were between 25 and 34 years old and $12 \%$ were $35-44$ years old. The majority of participants $(70 \%)$ had a length of service of 1 year or less.

\section{Measuring instrument}

The retention factor measurement scale (RFMS) was utilised for the study, as it aptly measures the retention factors supported by the literature. This scale was developed by Döckel et al. (2006) and measured retention factors and intention to leave. The scale consisted of 35 items. All items in the scale were presented on a five-point Likert scale ranging from 1 strongly disagree to 5 strongly agree. The instrument measured the participants' satisfaction with six retention factors: compensation, job characteristics, opportunities for training and development, supervisor support, career opportunities and work-life balance. In terms of measuring employee retention, the dimension intention to leave was used. The instrument measured the participants' satisfaction with six retention factors, and an example of the item is included next to each factor in brackets:

- Compensation ('On my present job this is how I feel about my benefits package').

- Job characteristics ('The job gives me considerable opportunity for independence and freedom in how I do the work').

- Opportunities for training and development ('There are enough development opportunities for $m e$ in this company').
- Supervisor support ('I feel valued by my supervisor').

- Career opportunities ('My chances of being promoted are good').

- Work-life balance ('My work schedule is often in conflict with my personal life').

- Intention to leave ('Do you intend to leave this company voluntarily in the near future?').

The reliability and validity of the RFMS were acceptable by Döckel et al. (2006, p. 23). The following Cronbach's alpha coefficients were reported: compensation 0.90, job characteristics 0.41, opportunities for training and development 0.83, supervisor support 0.90, career opportunities 0.76 , work-life balance 0.87 and commitment to the organisation 0.89. In another study, Van Dyk and Coetzee (2012) reported acceptable Cronbach's alpha, namely compensation 0.95 , job characteristics 0.67 , opportunities for training and development 0.88 , supervisor support 0.83 , career opportunities 0.73 , work-life balance 0.88 and intention to leave 0.89 . In assessing reliability through Cronbach's alpha coefficient, this study utilised 0.70 as the level of acceptance. Nunnally and Bernstein (1994) suggest this as a rule of thumb that a level higher than 0.70 is considered for internal consistency.

\section{Research procedure}

Data were collected using a paper and pencil questionnaire over 2 days. The researchers went to the organisation and distributed the questionnaires to the station managers and agents. The respondents completed the questionnaires during their work time. The researchers obtained permission from the organisation to conduct the study. The organisation was provided with complete disclosure of the study and its purpose, objectives and benefits of the research, and guaranteed that the best interests of the organisation are protected. In addition, the researchers ensured that agreed time frame of the study was kept (in terms of data collection). All findings of the research will be shared with the organisation. In terms of participation in the study, respondents completed an informed consent noting that participation in the study was voluntary and anonymity was ensured. Respondents were made aware that they can withdraw from the study at any time. The researchers ensured that the instructions provided were clear and concise. Data were not shared with unauthorised people, thereby ensuring that the identities of respondents are protected.

\section{Statistical analysis}

The Statistical Programme for Social Sciences (SPSS, version 22) was used to analyse the data. Descriptive statistics and inferential statistics were calculated. In order to assess internal consistency and reliability, Cronbach's alpha coefficients were measured. Factor analysis was computed to ensure validity. Factor analysis was conducted by using the pattern matrix of the principal axis factor analyses using Varimax rotation with Kaiser normalisation. It identified five 
retention factors and an intention to leave factor. These factors accounted for $55 \%$ of the total variance. The reliability of the questionnaire was statistically assessed using Cronbach's alpha coefficient.

In order to determine the direction and strength of the relationships between the variables, Pearson's productmoment correlations were calculated.

Multiple regression analysis was utilised to assess the way in which a set of variables are able to predict a particular outcome (Pallant, 2007). This study looks at the way in which retention factors (independent variable) predict intention to leave (dependent variable).

Analysis of variance was used to assess whether employees differing in biographical profiles (age, type of work, race, tenure and levels of contract significantly differ in their perceptions of the factors that affect retention).

T-tests were used to determine whether male or female call centre agents experience higher or lower intention to leave and to understand which factors do male and female employees perceive as an important factor of retention.

\section{Results \\ Descriptive statistics}

From Table 1, the study identified that having supervisor support is an important retention factor (mean = 3.69); this is closely followed by training and development (mean $=3.65$ ). However, employees believe that experiencing work-life balance (mean $=3.45$ ) is as important. Furthermore, employees perceived career advancement (mean $=2.94)$ to be a fair retention factor, closely followed by compensation (mean $=2.85)$. The low mean value for intention to leave (mean $=2.74$ ) accounts for the aforementioned retention factors; employees are not likely to remain in the organisation. All items received the minimum and maximum responses on the Likert scale. The mean ranged from 2.74 to 3.69 and the standard deviation ranged from 0.71 to 1.06 .

\section{Frequency analyses for the possibility of enhancing retention}

Based on the frequency analyses, call centre organisations should be cognisant of the following as a possibility of enhancing employee retention:
- In terms of compensation, $56.23 \%$ of respondents reflected dissatisfaction with their most recent pay increase. Many respondents remained neutral in terms of compensation, namely, $51.6 \%$ of respondents were neutral in terms of supervisors' influence on their pay.

- With regard to training and development, $84.4 \%$ of respondents felt that their organisation provides them with training specific to their jobs. However, $36.1 \%$ of respondents remained neutral on whether sufficient money is allocated for product and solution training.

- In terms of supervisor support, $67.4 \%$ of respondents reflected that their supervisor lets them know how well they are performing on the job, whilst $38.7 \%$ of respondents remained neutral on whether their supervisor rewards a good idea by implementing it and giving the responsible employee(s) credit.

- In terms of career advancement, 52.1\% of respondents felt that an employee who applies for another job in the organisation has a better chance of getting that job than someone from outside the organisation who applies for the same job; $44.1 \%$ of respondents were neutral in terms of whether it would be easy to find a job in another department.

- In terms of work-life balance, $63.9 \%$ of respondents indicated that their work schedule is often in conflict with their personal life.

- With regard to intention to leave, $40 \%$ of respondents expressed that they are not likely to have plans to stay with the organisation, $31.9 \%$ remained neutral on how they would rate their chances of still working in the organisation a year from now and $21.4 \%$ indicated that they are likely to leave the organisation voluntarily in the near future.

Based on the frequency analysis, it is suffice to say that call centre agents place emphasis on the retention factors. However, there were instances where a significant amount of call centre agents remained neutral, namely, supervisors' influence on their pay, allocation of money for training and rewarding a good idea by their supervisor. Respectively, this could allude to that employees within the call centre are uncertain in terms of pay practices and the administration of having budgets for training. On the contrary, it should be noted that most call centre agents are satisfied with training and development provided by the organisation. Most call centre organisations provide job-specific training to their employees to equip them with the necessary skills required to perform their jobs. When employees are confident with performing their work, they tend to be motivated to work harder and are

TABLE 1: Descriptive statistics for retention factors and intention to leave dimensions.

\begin{tabular}{|c|c|c|c|c|c|c|c|c|}
\hline \multirow[t]{2}{*}{ Dimension } & \multirow[t]{2}{*}{$N$} & \multirow[t]{2}{*}{ Valid missing } & \multirow[t]{2}{*}{ Mean } & \multicolumn{2}{|c|}{$95 \%$ Confidence interval for mean } & \multirow{2}{*}{$\begin{array}{l}\text { Standard } \\
\text { Deviation }\end{array}$} & \multirow[t]{2}{*}{ Minimun } & \multirow[t]{2}{*}{ Maximum } \\
\hline & & & & Lower bound & Upper bound & & & \\
\hline Compensation & 281 & 1 & 2.85 & 2.76 & 2.93 & 0.71 & 1.00 & 5.00 \\
\hline $\begin{array}{l}\text { Training and } \\
\text { development }\end{array}$ & 281 & 1 & 3.65 & 3.56 & 3.74 & 0.76 & 1.00 & 5.00 \\
\hline Supervisor support & 281 & 1 & 3.69 & 3.61 & 3.78 & 0.71 & 1.33 & 5.00 \\
\hline $\begin{array}{l}\text { Career } \\
\text { advancement }\end{array}$ & 281 & 1 & 2.94 & 2.85 & 3.04 & 0.83 & 1.00 & 5.00 \\
\hline Intention to leave & 277 & 5 & 2.74 & 2.62 & 2.87 & 1.06 & 1.00 & 5.00 \\
\hline
\end{tabular}


more likely to commit themselves to the organisation (Armache, 2014).

Table 2 indicates that a relationship between the dependent and independent variables exists. According to Pallant (2007), a correlation of 1.0 suggests that there is a perfect relationship between the variables regardless of the direction of the relationship. The closer the $r$ value is to 1.0, the more satisfied the employees are with the retention factors and the more likely they are to remain in the organisation. The $r$ value ranged from 0.35 to 0.52 , representing moderate to strong relationship. Work-life balance had a significant negative relationship with intention to leave, as opposed to other retention factors which had a positive correlation.

A multiple regression analysis was calculated to predict intention to leave based on the retention factors. A significant retention equation was found $[\mathrm{F}(4.267)=46.082, p<0.000]$, with an $R^{2}$ of 0.408 . Table 3 indicates that the total variance in the dependent variable (intention to leave) explained in the model was $40.8 \%\left(R^{2}\right)$, and presents the significant results. In terms of multicollinearity, the current study yielded tolerance values close to 1.0 (between $\geq 0.642$ and $\leq 0.841$ ) and Variance inflation factor (VIF) values of $\leq 1.55$. They are lower than the cut-off of $\geq 2.5$ to $\geq 4.0$, suggested for small samples. Therefore, multicollinearity was not a particular concern in the context of the current study, and hence beta $(\beta)$ values are interpreted with more confidence.

Table 3 also indicates how the variables contributed to the prediction of the dependent variable (intention to leave). Compensation had the largest beta coefficient (0.268), suggesting that compensation contributes towards intention to leave more than the other factors, followed by work-life balance $(-0.237)$ which negatively contributed, then career advancement (0.240) and lastly supervisory support which had the smaller beta coefficient (0.112). Training and development was excluded from the model as it did not contribute to intention to leave as it had a beta coefficient of -0.009 . It is evident that the retention factors contribute significantly and positively to the variance of intention to leave.

From Table 4, it is evident that all factors scored relatively high reliability coefficients, ranging from 0.717 (the lowest) to 0.933 (the highest). The current study utilised 0.70 as the level of acceptance. It is evident that retention factors and intention to leave show a high level of internal consistency and stability.

Internal consistency for all factors was also noted and so were the average inter-item correlation coefficients. The values ranged between 0.337 and 0.702 . A reasonably high correlation between the factors and their component items was noted. Notably, all items loaded on a factor loading $>0.3$. The KaiserMeyer-Olkin measures of sampling adequacy ranged from 0.702 to 0.939 for each factor which exceeds the recommended value of 0.6. Barlett's test of sphericity also reached statistical significance $(p<0.001)$ and supports the factorability of the correlation matrix (Pallant, 2007). It is notable that normality and homoscedasticity preconditions for the study are fulfilled. It must be noted that the factor of job content was removed for the following reasons, namely, the Kaiser-Meyer-Olkin measures of sampling adequacy value reported was less than 0.6 and had communalities of less than 0.3 .

\section{Inferential statistics}

An independent samples $t$-test was conducted to compare the retention factors and intention to leave for male and female employees. From Table 5, it is evident that there was no significant difference in scores for male and female employees with regard to retention factors. Notably, the effect sizes for the

TABLE 2: Pearson correlation.

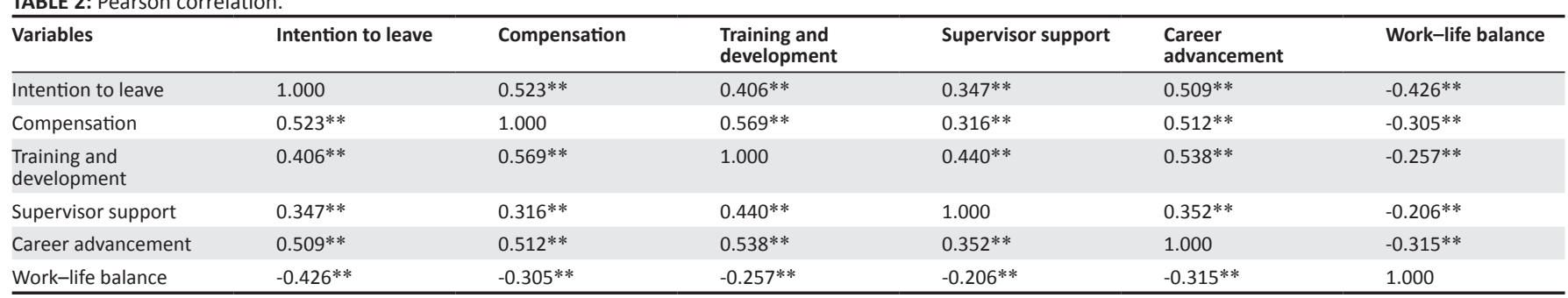

$* *, p \leq 0.01$

TABLE 3: Multiple regression analysis.

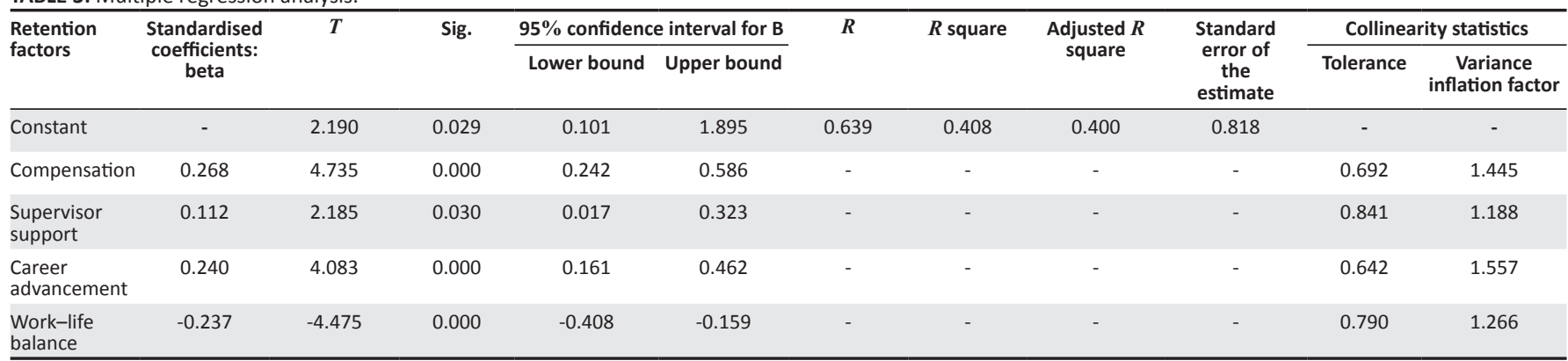

$T, t$ statistic; Sig, Significance; $R$, correlation coefficient; $R^{2}$, coefficient of determination. 
TABLE 4: Factor analysis for Retention Factor Scale.

\begin{tabular}{|c|c|c|c|c|c|}
\hline Factors & $\begin{array}{l}\text { Factor } \\
\text { loading }\end{array}$ & $\begin{array}{c}\text { Kaiser- } \\
\text { Meyer-Olkin }\end{array}$ & $\begin{array}{l}\text { Reliability } \\
\text { coefficient }\end{array}$ & $\begin{array}{c}\text { Mean } \\
\text { inter-item } \\
\text { correlation }\end{array}$ & $\begin{array}{c}\text { Variance \% } \\
\text { explained }\end{array}$ \\
\hline Compensation & - & 0.939 & 0.933 & 0.520 & 51.57 \\
\hline q1_7) & 0.808 & - & - & - & - \\
\hline q1_8 & 0.793 & - & - & - & - \\
\hline q1_4 & 0.767 & - & - & - & - \\
\hline q1_11 & 0.755 & - & - & - & - \\
\hline q1_9 & 0.724 & - & - & - & - \\
\hline q1_5 & 0.723 & - & - & - & - \\
\hline q1_12 & 0.717 & - & - & - & - \\
\hline q1_1 & 0.703 & - & - & - & - \\
\hline q1_3 & 0.702 & - & - & - & - \\
\hline q1_10 & 0.699 & - & - & - & - \\
\hline q1_13 & 0.685 & - & - & - & - \\
\hline q1_2 & 0.663 & - & - & - & - \\
\hline q1_6 & 0.562 & - & - & - & - \\
\hline $\begin{array}{l}\text { Training and } \\
\text { development }\end{array}$ & - & 0.837 & 0.875 & 0.547 & 54.64 \\
\hline q1_20 & 0.814 & - & - & - & - \\
\hline q1_19 & 0.809 & - & - & - & - \\
\hline q1_22 & 0.742 & - & - & - & - \\
\hline q1_21 & 0.695 & - & - & - & - \\
\hline q1_18 & 0.693 & - & - & - & - \\
\hline q1_23 & 0.668 & - & - & - & - \\
\hline $\begin{array}{l}\text { Supervisor } \\
\text { support }\end{array}$ & - & 0.702 & 0.717 & 0.337 & 50.54 \\
\hline q1_24 & 0.707 & - & - & - & - \\
\hline q1_29 & 0.637 & - & - & - & - \\
\hline q1_26 & -0.579 & - & - & - & - \\
\hline q1_25 & -0.574 & - & - & - & - \\
\hline q1_27 & 0.569 & - & - & - & - \\
\hline $\begin{array}{l}\text { Career } \\
\text { advancement }\end{array}$ & - & 0.736 & 0.788 & 0.480 & 49.76 \\
\hline q1_31 & 0.876 & - & - & - & - \\
\hline q1_30 & 0.699 & - & - & - & - \\
\hline q1_35 & 0.650 & - & - & - & - \\
\hline q1_33 & 0.557 & - & - & - & - \\
\hline $\begin{array}{l}\text { Work-life } \\
\text { balance }\end{array}$ & - & 0.766 & 0.814 & 0.522 & 54.27 \\
\hline q1_37 & 0.821 & - & - & - & - \\
\hline q1_38 & 0.798 & - & - & - & - \\
\hline q1_39 & 0.767 & - & - & - & - \\
\hline q1_36 & 0.522 & - & - & - & - \\
\hline $\begin{array}{l}\text { Intention to } \\
\text { leave }\end{array}$ & - & 0.741 & 0.875 & 0.702 & 70.25 \\
\hline q1_41 & 0.864 & - & - & - & - \\
\hline q1_42 & 0.828 & - & - & - & - \\
\hline q1_40 & 0.822 & - & - & - & - \\
\hline
\end{tabular}

retention factors are small and ranged from 0.00 (smallest) to 0.09 (largest). In terms of intention to leave, male participants experienced higher intention to leave than women participants $($ mean $=3.077$ vs. mean $=2.570)$. Cohen's $d$ refers to an appropriate effect size for the comparison between two means, whereby the standardised difference between two means, and expresses this difference in standard deviation units.

\section{Discussion}

The study provided insights on how retention factors relate to intention to leave in the context of a South African call centre. In addition, the study further provided insights into which retention factor best predicts intention to leave. The study examined the retention factors identified by Döckel et al. (2006) and how various biographical factors differed in terms of these factors. In terms of the frequency analysis, the discussion below presents the way in which call centre agents perceived the retention factors. Notably, line managers and human resource practitioners need to be cognisant of such factors as this will enhance the retention of call centre agents.

\section{Supervisor support}

With regard to supervisor support, an average mean value of 3.69 (maximum $=5)$ was obtained. This indicates that most of the respondents agree that they receive support from their supervisors. By contrast, Pierre and Tremblay (2011) found that supervisors in call centre organisations use authoritative measures to monitor and keep records of agents' calls and, as a result, agents experience high levels of uncertainty and discomfort which decrease their levels of job satisfaction. Even though strict measures are used to manage the call centre environment, in most organisations supervisors take it upon themselves to ensure that employees work in an environment where they are supported (Russel, 2008).

\section{Work-life balance}

With regard to work-life balance, an average mean value of 3.45 (maximum = 5) was obtained. This indicates that employees agree that they do not have a balance between work and their personal lives. Scott-Ladd, Travaglione, Perryer and Pick (2010) found that employees experienced conflict between their work and personal responsibilities as a

TABLE 5: Independent samples $t$-test - significant mean differences (gender).

\begin{tabular}{|c|c|c|c|c|c|c|c|}
\hline Variable & Gender & $N$ & Mean & Standard deviation & $p$ (two-tailed) & Cohen's $d$ & Effect size $r$ \\
\hline \multirow[t]{2}{*}{ Compensation } & Male & 91 & 2.916 & 0.69 & 0.306 & 0.13 & 0.06 \\
\hline & Female & 177 & 2.826 & 0.68 & - & - & - \\
\hline \multirow{2}{*}{$\begin{array}{l}\text { Training and } \\
\text { development }\end{array}$} & Male & 91 & 3.654 & 0.72 & 0.950 & -0.01 & 0.00 \\
\hline & Female & 177 & 3.660 & 0.75 & - & - & - \\
\hline \multirow[t]{2}{*}{ Supervisor support } & Male & 91 & 3.655 & 0.64 & 0.445 & -0.09 & 0.05 \\
\hline & Female & 177 & 3.723 & 0.71 & - & - & - \\
\hline \multirow[t]{2}{*}{ Career advancement } & Male & 91 & 3.064 & 0.86 & 0.129 & 0.19 & 0.09 \\
\hline & Female & 178 & 2.904 & 0.79 & - & - & - \\
\hline \multirow[t]{2}{*}{ Work-life balance } & Male & 91 & 3.450 & 0.89 & 0.656 & -0.05 & 0.03 \\
\hline & Female & 178 & 3.501 & 0.89 & - & - & - \\
\hline \multirow[t]{2}{*}{ Intention to leave } & Male & 91 & 3.077 & 1.05 & 0.000 & 0.47 & 0.23 \\
\hline & Female & 177 & 2.570 & 1.02 & - & - & - \\
\hline
\end{tabular}


result of working long hours and shifts that limit them from focusing on other life commitments. This may then hinder the organisations' progress in terms of the retention of employees as employees prefer to live a more flexible lifestyle (Snelgar, Renard \& Venter, 2013). It is important that organisations implement strategies aimed at enhancing work-life balance to assist employees in the pressures of their family and work areas (Amah, 2010).

\section{Career advancement}

In terms of career advancement, an average mean value of 2.94 (maximum = 5) was obtained. This indicates that employees disagree that they receive opportunities to grow within the organisation. A lack of growth opportunities (career advancement) has been found to have a negative influence on an individual's attitude towards the organisation, which in turn influences their intention to leave (Van Dyk, Coetzee \& Takawira, 2013). Likewise, Shoaib, Noor, Tirmizi and Bashir (2009) also emphasised the importance of career development as they indicated that the development of the employee plays a crucial part in the development of the organisation and therefore the organisation has to create an environment that enhances this development and growth. Organisations need to attend to employees' career advancement needs as they greatly affect employee's decisions in terms of whether they see a future with the organisation (Das et al., 2013).

\section{Compensation}

In terms of compensation, an average mean value of 2.85 $($ maximum $=5)$ was obtained. This indicates that employees are not satisfied with the compensation they receive from the organisation. Likewise, Harry and Coetzee (2013) found that call centre organisations are characterised by low pay, and as a result, employees may look for alternative work elsewhere with a better compensation plan, thus increasing employees' intentions to leave the organisation. Employees are motivated by an attractive salary package; it provides a greater reason to perform tasks to the best of their abilities which then also benefits the organisation positively (Nagadevara et al., 2008).

The study provided insights on male or female call centre agents' intention to leave and if there is a difference in views of employees varying biographical data regarding relationship retention factors.

\section{Intention to leave and biographical data}

The biographical variables, gender and level of education are strong predictors of employee turnover. In this study, it was found that male participants experience higher intention to leave than women. The study revealed that male call centre agents experienced higher intention to leave than their female counterparts. Scholarios and Taylor (2008) alluded that call centre work is typically seen as female-oriented work. This alludes to the fact that women display higher levels of interpersonal skills than their male counterparts. According to Bonds (2006, p. 31), 'women are more patient, have better telephone conduct, and the ability to communicate well with customers'. It was also added that men tend to distance themselves from this type of work and pursue advancement opportunities (Scholarios \& Taylor, 2008). A study by Miller and Hendrickse (2016) revealed that within a call centre environment, men experienced a higher level of exhaustion than women. Exhaustion is a result of being continuously exposed to high work pressures and work overload which are some of the characteristics of call centre work (Simons \& Buitendach, 2013). This may lead to men constantly feeling drained after work, thereby increasing their intentions to leave. In terms of intention to leave, those participants who are in possession of a grade 12 or equivalent experience higher intention to leave than those with a higher level of education. This may be because they want to go to further their studies.

\section{Intention to leave}

The study emphasised the significance of employee retention, which is explained as a way of keeping employees within the organisation by reducing or terminating their intentions to leave. Pierre and Tremblay (2011) noted the difficulty of managers to retain employees (in this case, call centre agents), resulting in high rates of turnover within the call centre organisation. Intention to leave obtained an average mean value of 2.74 (maximum $=5$ ) was obtained. This indicates that majority of the respondents are not likely to stay with the organisation in the near future owing to dissatisfaction with the retention factors. Likewise, Van Rensburg et al. (2013) found that there was a high rate of employee turnover in call centre organisations. Retention factors such as compensation, career advancement, worklife balance and supervisor support contributed significantly in motivating employees to stay in the organisation and it is advised that management focus on them in order to retain their employees.

\section{Retention factors and intention to leave}

The results revealed that there is a significant relationship between the retention factors (compensation, career advancement, work-life balance and supervisor support) and intention to leave in the context of a South African call centre. Work-life balance had a negative significant relationship to intention to leave. As work-life balance decreases call centre agents' intention to leave will increase. In this likelihood, call centre organisations need to provide opportunities for their agents to have a balanced lifestyle.

In terms of the overall fit of the model, as indicated by the $R^{2}$, compensation contributed the most towards employee's intentions to leave the organisation and can be regarded as the best predictor of intention to leave. Compensation plays a vital role in attracting employees and influencing 
individuals to greatly commit to the organisation (Chew \& Chan, 2008). It was also emphasised that employees work for the sake of earning a salary or wage. Hence, if they are not paid well, they may seek alternative employment that compensates well. Subsequently, career advancement contributed as a predictor of intention to leave. Meier et al. (2010) emphasised that it is not all employees who do not mind doing the same job forever; most employees, especially younger generation, want to advance in their careers and develop their skills and knowledge. If an organisation does not provide them with such opportunities, they may seek those opportunities in other organisations regardless of whether they are paid well or not.

Work-life balance had a negative contribution towards intention to leave. As work-life balance decreases for call centre agents, their chances of leaving the organisation increase. Employees need enough time to take care of other personal commitments such as spending time with family to ensure that both their work life and personal life is balanced. If there is conflict between their work and personal life, they may experience exhaustion and end up not being able to cope with their work and it may lead to job dissatisfaction and increase employee's intention to leave the organisation (Simons \& Buitendach, 2013). Supervisor support was the least important factor. However, this does not mean that it does not contribute to the retention of employees. Van Dyk, Coetzee and Takawira (2013) indicated that supervisor support positively enhanced the participants' feelings of organisational fit. Such feelings include satisfaction with the feedback provided by the supervisor, feeling valued and being rewarded and recognised for ideas and work well done. These feelings motivate employees to stay with the organisation.

\section{Limitations of the study}

This study has a few limitations. Firstly, the scope of the study limited the generalisation of the results in that it only focused on one call centre organisation in Gauteng and cannot be generalised to other industries. Hence, future studies should incorporate other call centres in varying industries. Secondly, the use of hard copy questionnaires resulted in participants not answering some of the questions. Quantitative studies are characterised by the potential of common method bias as a result of influences such as social desirability and transient mood states (Podsakoff, MacKenzie, Lee \& Podsakoff 2003; Spector 1994). The design of the study looked at one point in time. In addition, using a convenience sample results in possible bias in data gathering and difficulties in generalising the results. Lastly, future studies on this topic should adopt a qualitative stance to gain insights into employee experiences.

\section{Recommendation and managerial implications}

Based on the findings of the study, recommendations for the study are diagrammatically represented in Figure 1, which when implemented have the potential to enhance employee retention within call centres.

The study can be utilised by human resource practitioners in call centre organisations to develop and implement strategies to enhance employee retention. This study concentrates on one sector; however, the findings of the study can be applied to other industries, depending on the work environment. Human resource practitioners need to be cognisant of retention factors that enhance employee retention.

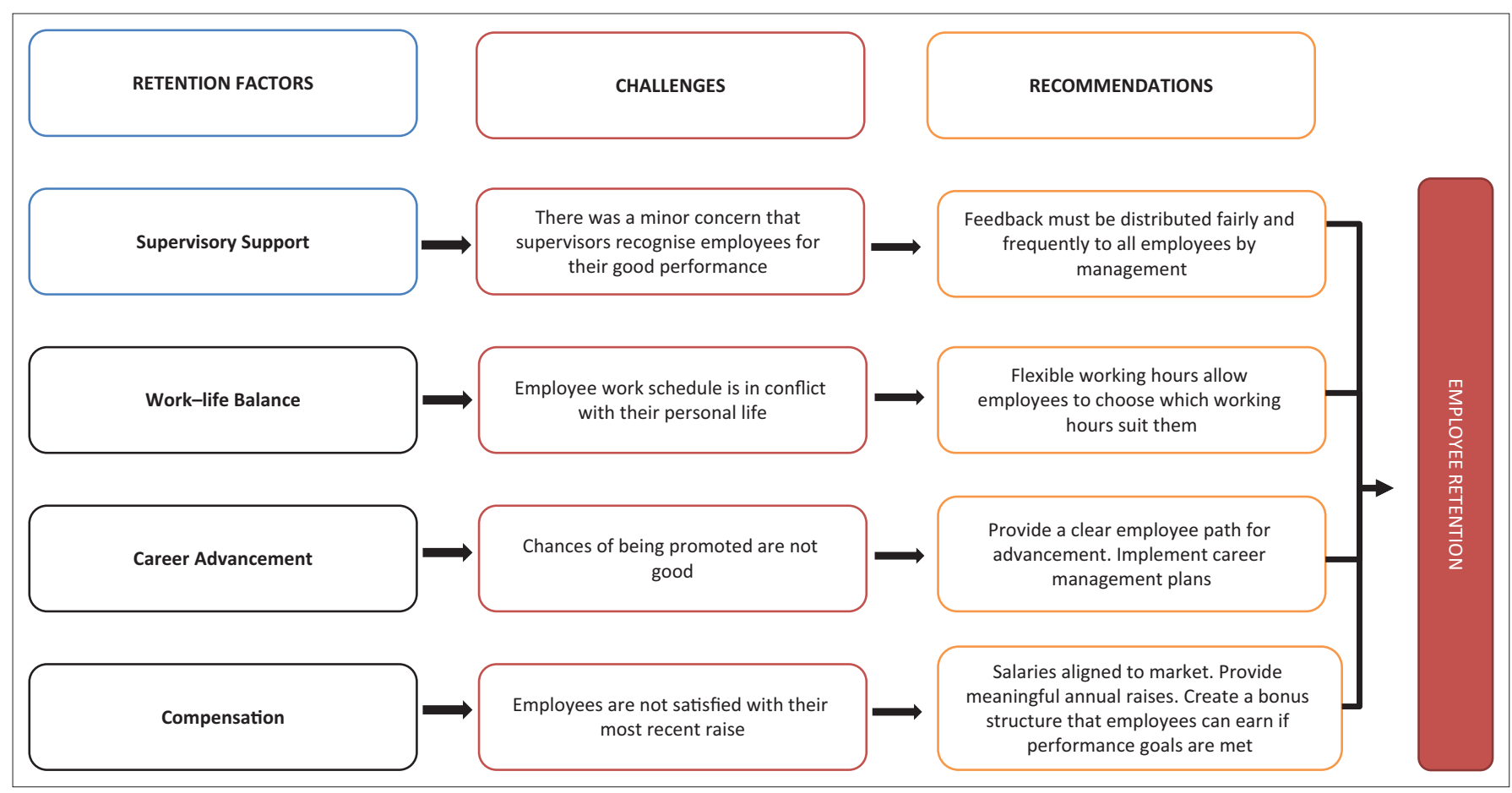

FIGURE 1: Recommendations on how to enhance employee retention. 


\section{Recommendations for future research}

Future research may focus on more than one organisation in order to enhance the generalisation of results. Factors (training and development and job content) that were excluded from the results may be repeated to determine if they will add value for future study. Future researchers should undertake a qualitative research design which will assist in providing a deeper understanding of retaining call centre agents and provide greater context into reasons they leave.

\section{Conclusion}

This study provided insights in terms of factors affecting retention of call centre agents and their levels of intention to leave. The findings of the study suggest that certain retention factors are crucial in influencing employees' intention to leave. Such factors include compensation, career advancement, supervisor support and work-life balance. Nonetheless, the importance of other factors (job content and training and development) should not be taken for granted when developing retention strategies. The study contributed theoretically and empirically towards the literature on employee retention. From this, it is evident that human resource practitioners and management staff of call centre organisations need to be cognisant of such factors and heed the recommendations provided. In order to enhance retention and yield low turnover rates, call centre organisations are encouraged to ensure that agents are remunerated well, and are provided with a work environment where they are able to grow and advance, in addition to a work environment that supports their work and personal life.

\section{Acknowledgements}

We thank Ms. Juliana Van Staden (Statistical Consultation Services at the University of Johannesburg) for assisting with the statistical analysis.

\section{Competing interests}

The authors declare that they have no financial or personal relationships that may have inappropriately influenced them in writing this article.

\section{Authors' contributions}

N.D. was the supervisor of the study and was responsible for consolidating and preparing the manuscript. F.D.M. was responsible for assisting in preparing the manuscript. F.D.M, P.L., R.M. and M.P. were students and contributed to the report for their research project.

\section{References}

Allen, D.G., Bryant, P.C., \& Vardaman, J.M. (2010). Retaining talent: Replacing misconceptions with evidence-based strategies. Academy of Management Perspectives, 24(2), 48-64. https://doi.org/10.5465/AMP.2010.51827775

Altarawmneh, I., \& Al-Kilani, M.H. (2010). Human resource management and turnover intentions in the Jordanian hotel sector. Research and Practice in Human Resource Management, 18(1), 46-59.
Amah, O.E. (2009). Satisfaction and turnover intention relationship: The moderating effect of job role centrality and life satisfaction. Research and Practice in Human Resource Management, 17(1), 24-35. https://doi.org/10.1080/09585192.2012.665067

Amah, O.E. (2010). Family-work conflict and the availability of work-family friendly policy relationships in married employees: The moderating role of work centrality and Career consequence. Research and Practice in Human Resource Management, 18(2), 35-46.

Armache, J. (2014). Ways and means to keep employees motivated, productive, and loyal. Journal of International Diversity, 2014(2), 87-103.

Barnes, N. (2013). The retention factors of call centre agents at a financial institution in the western cape. Master administrationis faculty of economic and management sciences department of industrial psychology university of the western cape, South Africa: University of Western Cape, pp. 1-159.

Bonds, A. (2006). Calling on femininity? Gender, call centers, and restructuring in the rural American West. ACME: An International Journal for Critical Geographies, 5(1), 28-49.

Burke, R.J., \& Cooper, C.L. (2009). The peak performing organization. New York: Routledge.

Chew, J \& Chan, C.C.A. (2008). Human resource practices, organizational commitment and intention to stay. International Journal of Manpower, 29(6), 503-522. https:// doi.org/10.1108/01437720810904194

Cianni, M. \& Gundy, P. (2012). Putting performance back into retention. Financia Executive, 28(9), 72-77.

Coetzee, M., \& Harry, N. (2015). Gender \& hardiness as predictors of career adaptability: An exploratory study among black call centre agents. SA Journal of Psychology, 45(1), 81-92. https://doi.org/10.1177/0081246314546346

Cohen, J. (1988). Statistical power analysis for the behavioral sciences (2nd ed.). New York: Lawrence Earlbaum Associates.

Das, D., Nandialath, A., \& Mohan, R. (2013). Feeling unsure: Quit or stay? Uncovering heterogeneity in employees' intention to leave in Indian call centers. The heterogeneity in employees intention to leave in Indian call centers. The
International Journal of Human Resource Management, 24(1), 15-34. https://doi. org/10.1080/09585192.2012.665067

Dhanpat, N., \& Parumasur, S.B. (2014). Re-establishing the psychological contract as a precursor to employee retention. Problems and Perspectives in Managemement, 12(4), 78-90.

Döckel, A., Basson, J.S., \& Coetzee, M. (2006). The effect of retention factors on organisational commitment: An investigation of high technology employees. SA Journal of Human Resource Management, 4(2), 20-28. https://doi.org/10.4102/ sajhrm.v4i2.91

Du Plooy, J., \& Roodt, G. (2013). Biographical and demographical variables as moderators in the prediction of turnover intentions. SA Journal of Industria Psychology, 39(1), 12-24. https://doi.org/10.4102/sajip.v39i1.1070

Filwood, D. (2014). Why Do Your Call Center Agents Quit? May 18, Retrieved April 12, 2016, from https://www.linkedin.com/pulse/20140518182546-3995896-why-doyour-call-center-agents-quit/

Fleisher, M.S. (2011). Temporal patterns of functional and dysfunctional employee turnover. Doctoral dissertations. University of Tennessee. Retrieved 19 August, 2016, from http://trace.tennessee.edu/utk_graddiss/1181

Gayathri, R., Sivaraman, G.G., \& Kamalambal, R.R. (2012). Employee retention strategies in BPO's: An empirical investigation. Interdisciplinary Journal of Contemporary Research in Business, 3(12), 572-583.

Goodwin, R.E., Groth, M., \& Frenkel, S.J. (2011). Relationships between emotional labor, job performance, and turnover. Journal of Vocational Behavior, 79(2), 538548. http://doi.org/10.1016/j.jvb.2011.03.001

Grobler, A.P., Wärnich, S., Carrell, M.R., Elbert, N.F., \& Hatfield, R.D. (2011). Human resource management in South Africa (4th ed.). Hampshire: Cengage Learning.

Harry, N., \& Coetzee, M. (2013). Sence of coherence, career adaptability and burnout of early-career black staff in call centre environment. SA Journal of Industria Psychology, 39(2), 1-10. https://doi.org/10.4102/sajip.v3912.1138

Jacobs, C., \& Roodt, G. (2011). A human capital predictive model for agent performance in contact centres. SA Journal of Industrial Psychology, 37(1), 1-19. https://doi. org/10.4102/sajip.v37i1.940

Joāo, T.F., \& Coetzee, M. (2012). Job retention factors, perceived career mobility and organisational commitment in the South African financial sector. Journal of Psychology in Africa, 22(1), 69-76. https://doi.org/10.1080/14330237.2012.10874523

Karatepe, O. \& Aleshinloye, K. (2009). Emotional dissonance and emotional exhaustion among hotel employees in Nigeria. International Journal of Hospitality Management, 28, 96-104. https://doi.org/10.1016/j.ijhm.2008.12.002

Kashyap, V., \& Rangnekar, S. (2014). A structural equation model for mearsuring the impact of employee retention practices on employee's turnover intentions: An Indian perspective. South Asian Journal of Human Resources Management, 1(2) 221-247. https://doi.org/10.1177/2322093714549109

Khan, M.A.S., \& Du, J.G. (2014). An empirical study of turnover intentions in call centre industry of Pakistan. Journal of Human Resource and Sustainability Studies, 2(4), 206-214. https://doi.org/10.4236/jhrss.2014.24021

Korvajärvi, P. (2009). Attracting customers through practising gender in call-centre work. Work Organisation, Labour \& Globalisation, 3(1), 131-143. https://doi.org/ workorgalaboglob.3.1.0131

Kyndt, E., Dochy, F., Michielsen, M., \& Moeyaert, B. (2009). Employee retention: Organisational and personal perspective. Vocations and Learning, 2(1), 195-215. https://doi.org/10.1007/s12186-009-9024-7

Mafini, C., \& Dlodlo, N. (2014). The linkage between work-related factors, employee satisfaction and organisational commitment. Insights from public health professionals. SA Journal of Human Resource Management, 12(1), 1-12. https:// doi.org/10.4102/sajhrm.v12i1.616 
Marinucci, F., Majigo, M., Wattleworth, M., Paterniti, A.D., Hossain, M.B., \& Redfield, R. (2013). Factors affecting job satisfaction and retention of medical laboratory professionals in seven countries of Sub-Saharan Africa. Human Resources for Health, 11(1), 38. https://doi.org/10.1186/1478-4491-11-38

Mcculloch, M.C., \& Turban, D.B. (2007). Using person - Organization fit to select employees for high- turnover jobs. International Journal of Selection and Assessment, 15(1), 63-71. https://doi.org/10.1111/j.1468-2389.2007. and Assess

Miller, N., \& Hendrickse, R. (2016). Differences in call centre agents' perception of their job characteristics, physical work environment and wellbeing. Problems and Perspectives in Management, 14(1), 51-63. https://doi.org/10.21511/ ppm.14(1).2016.06

Meier, J., Austin, S.F., \& Crocker, M. (2010). Generation Y in the workforce: Managerial challenges. The Journal of Human Resource and Adult Learning, 6(1), 68-78.

Nagadevara, V., Srinivasan, V., \& Valk, R. (2008). Estanlishing a link between employee turnover and withdrawal behaviours: Application of data mining techniques. Research and Practive in Human Resource Management, 16(2), 81-99.

Neely, A., Bourne, M., \& Kennerley, M. (2003). Dysfunctional performance through dysfunctional measures. Cost Management, 17(5), 41-45.

Nunnally, J.C., \& Bernstein, I.H. (1994). Psychometric theory (3rd ed.). New York: McGraw-Hill.

Pallant, J. (2007). SPSS survival manual, a step by step guide to data analysis using SPSS (4th ed.). New York: McGraw Hill

Phillips, S., \& Irmhoff, A. (1997). Women and career development: A decade of research. Annual Review of Psychology, 48(32), 31-59. https://doi.org/10.1146/ annurev.psych.48.1.31

Pierre, X., \& Tremblay, D.G. (2011). Levels of involvement and retention of agents in call centres: Improving well-being of employees for the better socioeconomic performance. Journal of Management Policy \& Practice, 12(5), 53-71.

Pillay, K., Buitendach, J.H., \& Kanengoni, H. (2014). Psychoplogical capital, job demands and organisational commitment of employees in a call centre in Durban South Africa. SA Journal of Human Resource Management, 12(1). 1-13. https:// doi.org/10.4102/sajhrm.v12i1.599

Podsakoff, P.M., Mackenzie, S.B., Lee, JY, \& Podsakoff, N.P. (2003). Common method biases in behavioral research: A critical review of the literature and recommended remedies. Journal of applied psychology, 88(5), 879.

Rizwan, M., Arshad, M.Q., Munir, H.M., Iqbal, F., \& Hussain, A. (2014). Determinants of employees intention to leave. International Journal of Human Resource Studies, 4(3), 1-18. https://doi.org/10.5296/ijhrs.v4i3.5871

Russel, B. (2008). Call centres: A decade of research. International Journal of Management Reviews, 10(3), 195-214. https://doi.org/10.1111/j.1468-2370. 2008.00241.x

Scott-Ladd, B., Travaglione, A., Perryer, C., \& Pick, D. (2010). Attracting and retaining talent: Social organisational support as an emergent concept. Research and Practice in Human Resource Management, 18(2), 1-10.
Scholarios, D., \& Taylor, P. (2010). Gender, choice and constraint in call centre employment. New Technology, Work and Employment, 25(2), 101-116. https:// doi.org/10.1111/j.1468-005X.2010.00242.x

Sekaran, U., \& Bougie, R. (2013). Research methods for business. A skill building approach (6th ed.). West Sussex: Wiley.

Shoaib, M., Noor, A., Tirmizi, S.R., \& Bashi, S. (2009). Determinants of employee retention in telecom. Proceedings of the 2nd CBRC 14, 1-18.

Simons, J.C., \& Buitendach, J.H. (2013). Psychological capital, work engagement and organisational commitment amongst call centre employees in South Africa. SA Journal of Industrial Psychology, 39(2), 1-12. https://doi.org/10.4102/sajip v39i2.1071

Smit, W., Stanz, K., \& Bussin, M. (2015). Retention preferences and the relationship between total rewards, perceived organisational support and perceived supervisor support. SA Journal of Human Resource Management, 30(2), 1-13. https://doi.org/doi.org/10.4102/sajhrm.v13i1.665

Snelgar, R.J., Renard, M., \& Venter, D. (2013). An empirical study of the reward preferences of South African employees. SA Journal of Human Resource Management, 11(1), 1-14. https://doi.org/10.4102/sajhrm.v11i1.351

Spector, P.E. (1994). Using self-report questionnaires in OB research: A comment on the use of a controversial method. Journal of organizational behavior, 15(5), 385-392.

Takawiara, N., Coetzee, M., \& Schreuder, D. (2014). Job embeddedness, work engagement and turnover intention of staff in a higher education institution: An exploratory study. SA Journal of Human Resource Management, 12(1), 1-10. https://doi.org/10.4102/sajhrm.v12i1.524

Taylor, P., \& Bain, P. (1999). An assembly line in the head: Work and employee relations in the call centre. Industrial Relations Journal, 30(2), 101-117. https://doi. org/10.1111/1468-2338.00113

Tse, H.H., Lam, C.K., Lawrence, S.A., \& Huang, X. (2013). When my supervisor dislikes you more than me: The effect of dissimilarity in leader-member exchange on coworkers' interpersonal emotion and perceived help. Journal of Applied Psychology, 98(6), 974. https://doi.org/10.1037/a0033862

Van Dyk, J., \& Coetzee, M. (2012). Retention factors in relation to organisational commitment in medical and information technology services. SA Journal of Human Resource Management, 10(2). 1-11. https://doi.org/10.4102/sajhrm.v10i2.433

Van Dyk, J., Coetzee, M., \& Takawira, N. (2013). Satisfaction with retention factors as predictors of the job embeddedness of medical and information technology services staff. Southern African Business Review, 17(1), 57-75.

Van Rensburg, Y., Boonzaier, B., \& Boonzaier, M. (2013). The job demands-resources model of work engagement in South African call centres. SA Journal of Human Resource Management, 11(1), 1-13. https://doi.org/10.4102/sajhrm.v11i1.484

Van Rooyen, L., Du Toit, D. H., Botha, E., \& Rothmann, S. (2010). Artisan retention in an organisation in South Africa. SA Journal of Human Resource Management, 8(1), 1-8. http://doi.org/10.4102/sajhrm.v8i1.300

Wang, X., Wang, L., Xu, X., \& Ji, P. (2014). Identifying employee turnover risks using modified quality function deployment. Journal of Systems Research and Behavioural Science, 31(3), 398-404. https://doi.org/10.1002/sres.2282 